\title{
FALL FERTILIZATION AND COLD HARDINESS IN LANDSCAPE TREES
}

\section{By E. Thomas Smiley ${ }^{1}$ and A.M. Shirazi ${ }^{2}$}

\begin{abstract}
Fall fertilization is sometimes considered a predisposing factor for winter injury in urban landscape plants. This study was developed to determine if fall fertilization of selected landscape trees would affect winter hardiness. Over a 3-year period, 200 trees in Charlotte, North Carolina, U.S., were fertilized with $1.3 \mathrm{~kg} \mathrm{~N} /$ $100 \mathrm{~m}^{2}$ or $2.7 \mathrm{~kg} \mathrm{~N} / 100 \mathrm{~m}^{2}$ (3 or $6 \mathrm{lb} \mathrm{N} / 1,000 \mathrm{ft}^{2}$ ) from Bartlett Boost $^{\mathrm{TM}}$ (28-9-9), $1.3 \mathrm{~kg} \mathrm{~N} / 100 \mathrm{~m}^{2}$ (3 lb N/1,000 ft ${ }^{2}$ ) from urea (46-0-0), or left untreated as controls. Fertilizer was soil injected in September or October, and samples were collected at three times during the winter to determine cold hardiness. There were no reductions in hardiness for sawtooth oak (Quercus acutissima), trident maple (Acer buergeranum), or leyland cypress ( $\times$ Cupressocyparis leylandii). Crapemyrtle (Lagerstroemia indica), which is marginally hardy at the test location, and red maple (Acer rubrum) experienced statistically significant, but not biologically significant, loss of hardiness in January and February due to some fertilizer treatments.
\end{abstract}

Key Words. Winter injury; nitrogen fertilization; fertilization.

Winter injury occurs when the temperature of a plant part is lower than its tolerance level. When this low temperature threshold is exceeded, many cells die, leading to symptoms collectively known as winter injury. The conditions for winter injury are most common in the spring or fall as the tree is changing hardiness and unusually cold temperatures occur, or any time during the winter when extremely low temperatures are encountered.

Fall application of fertilizer is a common arboricultural practice. Harris et al. (1999) state that late summer or early fall is usually the most effective application time for fertilizers, due to nutrient uptake prior to the start of growth the following season. Early shoot growth is almost entirely dependent on the level of dormant-stored nutrients (Harris et al. 1999). Fertilizer is applied in the fall so that nutrients can be absorbed prior to cessation of root activity and will be available to the developing leaves the next spring.

Some practicianers believe that fall application of fertilizer, specifically those containing nitrogen, will promote less hardy growth that will be damaged in the winter [Powell 1990; Nighswonger 1992; Relf 1996; Wood 1997; Koelling and Kielbaso (no date)]. However, no research has verified this finding on woody ornamental landscape plants.

Concern about fall fertilization of landscape plants may have originated from damage that occurred on McIntosh apples in New Hampshire in 1935-1936. In this case, trees were grown in poorly drained sod culture with extremely low soil pH (4.65 to 5), received two applications [estimated rate of $1.4 \mathrm{~kg} / 100 \mathrm{~m}^{2}$ (3 lb N/1,000 ft ${ }^{2}$ ) each] of cyanamid fertilizer $\left(\mathrm{CaCN}_{2}, 22 \% \mathrm{~N}\right)$ within 6 months, and the trees experienced extremely high yields the previous season (Rawlings and Potter 1937). Cyanamid fertilizer is now known to produce intermediate products that are toxic to plants. Cyanamid is even used as a herbicide in planting beds (Tisdale and Nelson 1975). In attempts to duplicate the injury observed in New Hampshire, follow-up research was conducted in 1936 and 1937 (Tingley et al. 1939). They could duplicate the winter injury symptoms with fall fertilization but only at rates of ammonium sulfate of $5.4 \mathrm{~kg}$ $\mathrm{N} / 100 \mathrm{~m}^{2}$ (12 lb N/1,000 ft²) or greater. Tingley et al. (1939) concluded that "any ordinary amount of fertilizer could have been applied with perfect safety."

Additional studies on apple trees found correlation among fall fertilization and irrigation and a relative reduction in winter hardiness. Way (1954) studied apple trees that were fertilized with $1.4 \mathrm{~kg}$ or $3.2 \mathrm{~kg}$ ( 3 or $7 \mathrm{lb}$ ) of ammonium nitrate per tree or irrigated in the fall. All three treatments reduced winter hardiness. The fall irrigation reduced winter hardiness more than fall fertilization. Edgerton (1957) noted that October application of $1.4 \mathrm{~kg}$ ammonium nitrate per tree, when combined with heavy rain, reduced relative hardiness in November and December, but this relative reduction did not result in actual damage to the tree.

With pear trees, moderate rates of ammonium nitrate (estimated at 2.5 to $3 \mathrm{lb} \mathrm{N} / 1,000 \mathrm{ft}^{2}$, or 1.1 to $1.3 \mathrm{~kg} \mathrm{~N} / 100 \mathrm{~m}^{2}$ ) applied in early September reduced the early fall hardiness by $4^{\circ} \mathrm{C}\left(7^{\circ} \mathrm{F}\right)$, as compared to low rates (estimated at 0.8 to 1 lb N/1,000 $\mathrm{ft}^{2}$, or 0.35 to $0.43 \mathrm{~kg} \mathrm{~N} / 100 \mathrm{~m}^{2}$ ) applied at the same time (Raese 1997). March applications of the same rate also reduced fall hardiness. Leaf color and tree vigor were significantly better with the higher rate of nitrogen at either time of year. So with pears, time of fertilizer application was less important than rate. Even though hardiness was reduced with any fertilizer application, the fertilized plants appeared healthier.

With peach trees, the effects of fertilization appear somewhat mixed. Long-term studies in Georgia found that increased nitrogen levels in twigs were associated with increased resistance to winter injury (Myers 1996). Proebstring (1961), however, associated fall nitrogen application with lower level of hardiness.

Container-grown Forsythia with fertility levels maintained at high levels through the late summer and fall had no significant decrease in winter hardiness (Pellett 1973). The forsythia 
stems showed no injury at any nitrogen application level when exposed to $-24^{\circ} \mathrm{C}$ $\left(-11^{\circ} \mathrm{F}\right)$ temperatures in November.

Conifer results were more consistent: Fall fertilization increases winter hardiness. DeHayes et al. (1989), working with Picea rubens seedlings, found a $3.7^{\circ} \mathrm{C}$ $\left(6.6^{\circ} \mathrm{F}\right)$ increase in winter hardiness at the end of November with September application of ammonium nitrate at $2.7 \mathrm{~kg}$ $\mathrm{N} / 100 \mathrm{~m}^{2}$ (6 lb N/1,000 ft²). In November, the increase in hardiness from September application was slightly less than June or August application, but by January the September application had the greatest tolerance. DeHayes et al. (1989) also found that rates of up to $27 \mathrm{~kg} \mathrm{~N} / 100 \mathrm{~m}^{2}(60 \mathrm{lb} \mathrm{N} /$ $\left.1,000 \mathrm{ft}^{2}\right)$ applied at any time of the year had no detrimental effect on hardiness. Pellett and White (1969) found that early September fertilization increased winter hardiness of container grown Juniperus chinensis.

This trial was conducted to determine if fall fertilization of urban landscape trees using moderate levels of nitogen in accordance ANSI A300 standards (ANSI 1998) would reduce cold hardiness.

\section{MATERIALS AND METHODS}

Street and park trees in Charlotte, North Carolina, U.S., were selected for the study. Test species were sawtooth oak (Quercus acutissima), trident maple (Acer buergeranum), Leyland cypress ( $\times$ Cupressocyparis leylandii), crapemyrtle (Lagerstroemia indica), and red maple (Acer rubrum). Two hundred trees were included in the study, with 50 trees receiving each treatment. Trunk caliper measured $30.5 \mathrm{~cm}$ (12 in.) above the soil surface, ranging from 6 to $12 \mathrm{~cm}(2.5$ to 4.8 in.) (Table 1). Trees were mulched approximately halfway from the trunk to the drip line with pine needles; turf surrounded the mulch. Trees of each species were assigned one of the following fertilizer treatments or were left unfertilized as a control in completely randomized designs. Treatments were urea (46-0-0) applied at a rate of $1.3 \mathrm{~kg} \mathrm{~N} / 100 \mathrm{~m}^{2}$ (3 lb N/1,000 ft $\left.{ }^{2}\right)$ and Bartlett Boost ${ }^{\mathrm{TM}}(28$ 9-9 with $14 \%$ water insoluble nitrogen from Nitroform ${ }^{\mathrm{TM}}$ ) applied within the drip line of the tree at either $1.3 \mathrm{~kg} \mathrm{~N} / 100$ $\mathrm{m}^{2}$ or $2.7 \mathrm{~kg} \mathrm{~N} / 100 \mathrm{~m}^{2}$ (3 or $6 \mathrm{lb} \mathrm{N} / 1,000 \mathrm{ft}^{2}$, referred to as Boost 3 and Boost 6 , respectively). Fertilizers were mixed with water and injected into the soil to a depth of $20 \mathrm{~cm}(8$ in.) at a pressure of $1 \mathrm{MPa}(150 \mathrm{psi})$. Fertilizer was applied once to each set of trees. Application dates were September 2 and 3, 1997; September 16, 1998; and October 14, 1999.

Samples to determine cold hardiness were collected approximately 1 month after fertilizer application, midwin- ter, and just prior to budbreak (Table 1). Two to four twigs, approximately $30 \mathrm{~cm}$ (12 in.) long per tree, were collected from the middle crown, south side. All twig samples were shipped overnight to The Morton Arboretum in Lisle, Illinois.

Cold hardiness was determined by freezing tests as previously described by Shirazi and Fuchigami (1993, 1995). For deciduous trees, $2 \mathrm{~cm}$ (0.8 in.) long stem segments ( $n=4 /$ treatment/temperature) were cut from the second, third, and fourth internodes and placed in $10 \times 75$ $\mathrm{mm}$ glass vials containing $0.5 \mathrm{~mL}$ of water. Samples were placed in a circulating refrigerated ethylene glycol bath (Model $\mathrm{LT}_{50} \mathrm{NCSL} \mathrm{Lb}$ Inc, Newington, NH). After 30 minutes at $-2^{\circ} \mathrm{C}\left(29^{\circ} \mathrm{F}\right)$, the samples were nucleated with ice crystals and kept overnight at $-2^{\circ} \mathrm{C}$. The temperature was then lowered at a rate of $5^{\circ} \mathrm{C} / \mathrm{hr}$ to $-40^{\circ} \mathrm{C}\left(-40^{\circ} \mathrm{F}\right)$. Samples were taken out at each test temperature $\left(4^{\circ} \mathrm{C}\right.$ intervals). The samples were held at each test temperatures for 30 minutes, removed, and thawed at $40^{\circ} \mathrm{C}\left(104^{\circ} \mathrm{F}\right)$ for 24 hours.

Samples were then placed in $10 \mathrm{~cm}$ Petri dishes containing Watman No. 1 moist filter paper and incubated in the dark at $23^{\circ} \mathrm{C}\left(74^{\circ} \mathrm{F}\right)$ for 1 week. The $\mathrm{LT}_{50}$ was determined based on cambium tissue viability $(1=$ alive, $5=$ dead $)$.

For Leyland cypress trees, branches, leaves, and stems (n $=4 /$ treatment/temperature) were used for the freezing test. Samples were placed on moistened cheesecloth and crushed ice was added. Samples were wrapped in aluminum foil and placed in an ultra-low-temperature freezer (Model ULT 50, Scientemp Corp., Adrian, MI) and kept at $-2^{\circ} \mathrm{C}\left(29^{\circ} \mathrm{F}\right)$ overnight. The temperature was lowered at a rate of $5^{\circ} \mathrm{C} / \mathrm{hr}$ until $-40^{\circ} \mathrm{C}\left(-40^{\circ} \mathrm{F}\right)$ was achieved. Samples were taken out at $4^{\circ} \mathrm{C}$ intervals. After freezing, the samples thawed at $40^{\circ} \mathrm{C}$ ) 
$\left(104^{\circ} \mathrm{F}\right)$ for 24 hours. Stem and needles were processed and evaluated as previously described. Branches were planted in a peat and perlite media and kept at 100\% humidity in a greenhouse and evaluated after 2 weeks for visual browning and lowest survival temperature. The temperature at which $50 \%$ of the tissues were killed, $\mathrm{LT}_{50}$, was calculated by first fitting a sigmoidal curve through the data and determining the midpoint as the $\mathrm{LT}_{50}$ point.

Data were analyzed with a one-way analysis of variance and, when significant differences were found $(p<0.05)$, means were compared using the Duncan Multiple Range Test. Each species was independently statistically tested.

\section{RESULTS AND DISCUSSION}

No fall flushes of growth were noticed on any trees in the experiment. Fall fertilization of determinant-growth deciduous trees (i.e., maple and oak) had no consistant detrimental effect on cold hardiness. No $\mathrm{LT}_{50}$ values were significantly different at any sampling period for sawtooth oak or trident maple. With red maple in February 2000, the Boost 3 treatment corresponded to a significant reduction in hardiness (Figure 1). The Boost 3 mean $\mathrm{LT}_{50}$ was $-22^{\circ} \mathrm{C}$ $\left(-8^{\circ} \mathrm{F}\right)$ as compared to $-32^{\circ} \mathrm{C}\left(-26^{\circ} \mathrm{F}\right)$ with the nonfertilized controls. Since neither the urea nor the Boost 6 treatment was significantly higher than the control and there was no indication of a reduction in hardiness in November or January, this appears to be an aberration in the data.

Crapemyrtle mean $\mathrm{LT}_{50}$ values were not significantly different until the February prebud break sampling (Figure 2). At that point, both of the Boost treatments were less hardy than the control and urea treatments. The mean control $\mathrm{LT}_{50}$ was $-31^{\circ} \mathrm{C}\left(-13^{\circ} \mathrm{F}\right)$, while the mean Boost $3 \mathrm{LT}_{50}$ was $-16.7^{\circ} \mathrm{C}\left(-2^{\circ} \mathrm{F}\right)$ and Boost $6 \mathrm{LT}_{50}$ was $-20.5^{\circ} \mathrm{C}\left(-3^{\circ} \mathrm{F}\right)$. While crapemyrtle appears to be a potential problem species for fall fertilization, it must be noted that the lowest recorded temperatures in the Charlotte, North Carolina, area are $-16.7^{\circ} \mathrm{C}\left(2^{\circ} \mathrm{F}\right)$ in December, $-20.5^{\circ} \mathrm{C}$ $\left(-5^{\circ} \mathrm{F}\right)$ in January, and $-15^{\circ} \mathrm{C}\left(5^{\circ} \mathrm{F}\right)$ in February (NCDC 1999). Therefore, even though the hardiness reduction of crapemyrtle was statistically significant, the biological significance is minimal in this climatic region.

Results from Leyland cypress were not significantly different except for one point (Figure 3). In January, the Boost 6 treatment mean $\mathrm{LT}_{50}$ was significantly lower (more cold hardy) than the nontreated control (Figure 3). This finding is consistent with other conifer research in which fall fertilization also increased hardiness (Pellett and White 1969; DeHayes et al. 1989).

Three of the 15 treatment/species hardiness comparisons in this experiment exhibited reductions in cold hardiness. However, temperatures at which damage could occur have never been recorded in this region. Therefore, while these comparisons are statistically significant,

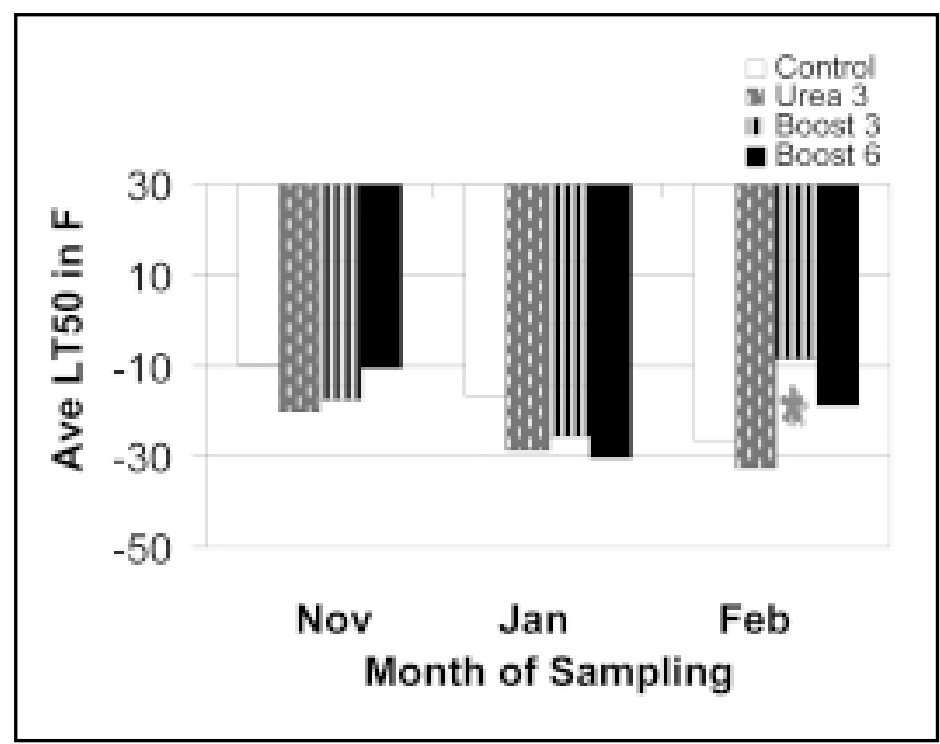

Figure 1. Mean temperature at which $50 \%$ of red maple samples were killed ( $\left.\mathrm{LT}_{50}\right)$ after trees were fertilized on October 14, 1999, with urea (46-0-0) applied at a rate of 1.3 $\mathrm{kg} \mathrm{N} / 100 \mathrm{~m}^{2}$, Boost (28-9-9) at 1.3 or $2.7 \mathrm{~kg} \mathrm{~N} / 100 \mathrm{~m}^{2}$, or left nonfertilized as a control. Means that are significantly different from the control using Duncan's Multiple Range Test $(p=0.05)$ are indicated with an asterisk.

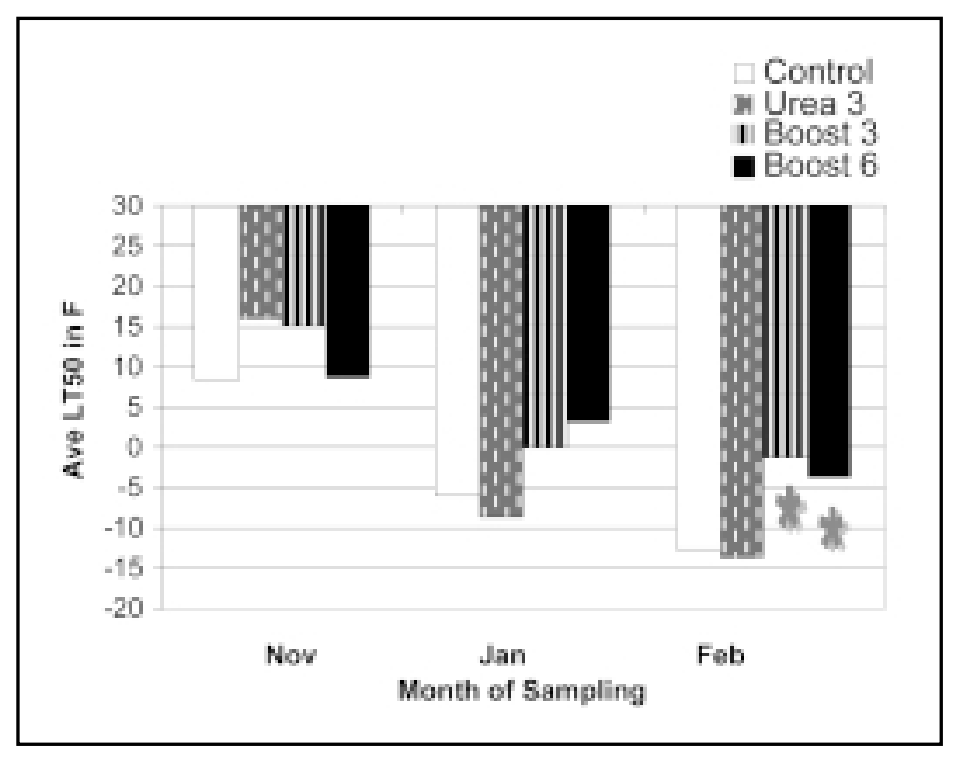

Figure 2. Mean temperature at which $50 \%$ of crapemyrtle samples were killed ( $\left.\mathbf{L T}_{50}\right)$ after trees were fertilized on September 16, 1998, with urea (46-0-0) applied at a rate of $1.3 \mathrm{~kg} \mathrm{~N} / 100 \mathrm{~m}^{2}$, Boost (28-9-9) at 1.3 or $2.7 \mathrm{~kg} \mathrm{~N} / 100 \mathrm{~m}^{2}$, or left nonfertilized as a control. Means that are significantly different from the control using Duncan's Multiple Range Test $(p=0.05)$ are indicated with an asterisk. 
they were not biologically significant. Overall, the results of this study were consistant with the majority of the published research on fall fertilization and winter hardiness (Tingley et al. 1939; Way 1954; Pellett and White 1969; Pellett 1973; DeHayes et al. 1989). Using the fertilizer rates outlined in the ANSI A300 tree and shrub fertilization standard (ANSI 1998), reduction in winter hardiness associated with fall fertilization of the determinant-growth hardwoods or conifers should not be a problem. The only species for which caution may be needed are indeterminant-growth species (species that have multiple growth flushes annually, such as crapemyrtle and apple). Winter injury is most likely to occur with species planted outside of their hardiness zones, after years of heavy fruit development, after late summer topping, or after excess fall irrigation/rainfall (Way 1954; Edgerton 1957).

\section{LITERATURE CITED}

American National Standards Institute (ANSI). 1998. A300 Standard for Tree Care Operations-Tree, Shrub, and Other Woody Plant MaintenanceStandard Practices (Fertilization, Part 2). American National Standards Institute, New York, NY.

DeHayes, D.H., M.A. Ingle, and C.E. White. 1989. Nitrogen fertilization enhances cold tolerance of red spruce seedlings. Can. J. For. Res. 19:1037-1043.

Edgerton, L.J. 1957. Effects of nitrogen fertilization on cold hardiness of apple trees. Proc. Am. Soc. Hortic. Sci. 70:40-45.

Harris, R.W., J.R. Clark and N.P. Matheny. 1999. Arboriculture: Integrated Management of Landscape Trees, Shrubs, and Vines (3rd ed.). Prentice Hall, Upper Saddle River, NJ. 687 pp.

Koelling, M., and J.J. Kielbaso. No date. Fertilizing Shade and Ornamental Trees. Michigan State University Extension Publication E786.

Myers, S.C. 1996. Ensure hardiness and spring crop now. Fruit Grower. Aug.:16.

National Climate Data Center (NCDC). 1999. Local Climatological Data for Charlotte NC (CLT). U.S. Dept. of Commerce, Asheville, NC.

Nighswonger, J.J. 1992. Fertilizing Trees and Shrubs. Kansas State and Extension Forestry Extension Publication L707R.

Pellett, N.E. 1973. Influence of nitrogen and phosphorus fertility on cold acclimation of roots and stems of two container-grown woody plant species. J. Am. Soc. Hortic. Sci. 98:82-86.

Pellett, N.E., and D.B. White. 1969. Effects of soil nitrogen and soil moisture levels on cold acclimation of container grown Juniperus chinensis "Hetzi". J. Am. Soc. Hortic. Sci. 94:457-459.

Powell, M.A. 1990. Fertilizing deciduous shade trees in the landscape. N.C. Horticulture Information Leaflet 618.

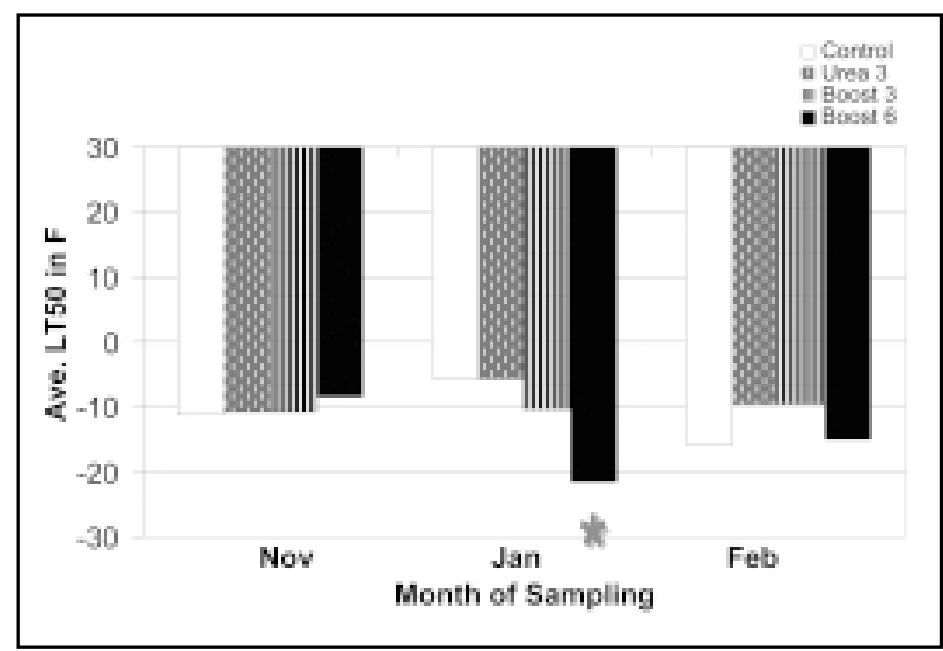

Figure 3. Mean temperature at which $50 \%$ of Leyland cypress samples were killed $\left(\mathbf{L T}_{50}\right)$ after trees were fertilized on September 16, 1998, with urea (46-0-0) applied at a rate of $1.3 \mathrm{~kg} \mathrm{~N} / 100 \mathrm{~m}^{2}$, Boost (28-9-9) at 1.3 or $2.7 \mathrm{~kg} \mathrm{~N} / 100 \mathrm{~m}^{2}$, or left nonfertilized as a control. Means that are significantly different from the control using Duncan's Multiple Range Test $(p=0.05)$ are indicated with an asterisk.

Proebstring, E.L. 1961. Cold hardiness of Elberta peach fruit buds as influenced by nitrogen level and cover crop. Proc. Am. Soc. Hortic. Sci. 77:97-106.

Raese, T.J. 1997. Cold tolerance, yield and fruit quality of d'Anjou pears influenced by nitrogen fertilizer rates and time of application. J. Plant Nutr. 20:1007-1025.

Rawlings, C.O., and G.F. Potter. 1937. Unusual and severe winter injury to the trunks of McIntosh apple trees in New Hampshire. Proc. Am. Soc. Hortic. Sci. 34:44-48.

Relf, D. 1996. Avoiding winter injury. Virginia Extension Publication 426-500.

Shirazi, A.M., and L.H. Fuchigami. 1993. Recovery of plants from "near-lethal" stress. Oecologia 93:429-433. 1995. Effect of near-lethal heat stress on bud dormancy and stem cold hardiness in red-osier dogwood. Tree Physiol. 15:275-279.

Tingley, M.A., W.W. Smith, T.G. Phillips, and G.F. Potter. 1939. Experimental production of winter injury to the trunks of apple trees by applying nitrogenous fertilizers in the autumn. Proc. Am. Soc. Hortic. Sci. 36:177-180.

Tisdale, S.L., and W.L. Nelson. 1975. Soil Fertility and Fertilizers (3rd ed.). Macmillan, New York, NY. 694 pp.

Way, R.D. 1954. The effects of some cultural practices and of size of crop on the subsequent winter hardiness of apple trees. Proc. Am. Soc. Hortic. Sci. 63:163-166.

Wood, G. 1997. Tree and Shrub Fertilization. Gardenline Extension Publication, University of Saskatchewan (www.ag.usask.ca/cofa/departments/hort/hortinfo/trees/ tree2.html). 
Acknowledgments. We would like to thank the following people who contributed to this study: Lynn Roberts, Craig Greco, Mike Sherwood, Bobby Walker, Stephen Smith, Terri VanZant, Lynn Roberts, Tom Martin, Dr. Don Booth, and Dr. Bruce Fraedrich of the Bartlett Tree Research Laboratories; Don McSween, Steve Ketner, Mike Arnold, and Jerry Orr with the City of Charlotte; and Kathi Roberts and Maurice Thierry from The Morton Arboretum.

\section{${ }^{1 *}$ Arboricultural Researcher \\ Bartlett Tree Research Laboratory \\ 13678 Hamilton Road \\ Charlotte, NC 28278, U.S. \\ and Adjunct Professor, Clemson University}

\section{${ }^{2}$ Researcher}

The Morton Arboretum

4100 Illinois Route 53

Lisle, IL 60532, U.S.

Résumé. La fertilisation d'automne est parfois considérée comme un facteur prédisposant pour les dommages hivernaux sur les végétaux en milieu urbain. Cette étude a été conçue afin de déterminer si la fertilisation d'automne de certains arbres sélectionnés pourrait affecter leur résistance contre l'hiver. Sur une période de trois ans, 200 arbres de Charlotte en Caroline du Nord ont été fertilisés de la manière suivante: $1,3 \mathrm{~kg}$ N/100 m² ou 2,7 kg N/100 m² (3 ou 6 lbs N/1000 pi²) de Bartlett Boost ${ }^{\text {TM }}$ (28-99), 1,3 kg N/100 m² (3 lbs/1000 pi²) d'urée (46-0-0), ou aucune fertilisation pour les arbres-témoin. L'engrais a été injecté dans le sol en septembre ou octobre, et des échantillons ont été recueillis à trois reprises durant l'hiver afin de vérifier le degré de résistance au froid. Il n'y a pas eu de diminution de la résistance au froid chez le Quercus acutissima, l'Acer buergeranum, ou le $\times$ Cupresssocyparis leylandii. Le Lagerstroemia indica qui est une espèce résistante de manière marginale sur le site d'essai, ainsi que l'Acer rubrum, ont expérimenté des pertes de résistance statistiquement significatives, mais non biologiquement significatives, en janvier et février dues à certains traitements de fertilisation.

Zusammenfassung. Die Herbstdüngung steht manchmal unter Verdacht, ein vorbestimmender Faktor für Winterverletzungen bei Pflanzen in der Stadt zu sein. Diese Studie wurde entwickelt, um zu bestimmen, ob Herbstdüngung die Winterhärte bestimmter ausgewählter Bäume beeinflussen würde. Über eine 3-jährige Periode wurden 200 Bäume in Charlotte NC mit 1,3 kg N/100 m² oder 2,7 kg N/100 m² Bartlett Boost ${ }^{\mathrm{TM}}$ (28-9-9), bzw. 1,3 kg N/100 m² Urea (46-0-0) gedüngt oder unbehandelt als Kontrollbäume in die Untersuchung einbezogen. Der Dünger wurde im September oder Oktober in den Boden eingebracht und anschließend wurden dreimal während des Winters Bodenproben gezogen, um die Frosthärte zu bestimmen. Es gab keine Reduktionen der Frosthärte bei Quercus acutissima, Acer buergeranum oder $\times$ Cupresssocyparis leylandii. Lagerstroemia indica, welche auf dem Teststandort winterfest ist und Acer rubrum reagierten statististisch relevant, aber nicht biologisch relevant aufgrund der Düngung einen Rückgang der Winterhärte in den Monaten Januar und Februar.

Resumen. La fertilización en el otoño es considerada algunas veces un factor que predispone a daños en invierno para las plantas. Este estudio fue desarrollado para determinar si serían afectados en el invierno árboles seleccionados que fueron fertilizados en otoño. En un período de tres años, 200 árboles en Charlotte NC fueron fertilizados con: $1.3 \mathrm{Kg}$. N/100 $\mathrm{m}^{2}$ o $2.7 \mathrm{Kg}$. N/100 m² (3 o 6 libras N/1000 pies cuadrados) del producto Bartlett Boost ${ }^{\mathrm{TM}}$ (28-9-9), 1.3 Kg. N/100 m² (3 libras N/1000 pies cuadrados) de urea (46-0-0), o dejados como controles no tratados. El fertilizante fue inyectado al suelo en Septiembre o Octubre y las muestras fueron colectadas en tres ocasiones durante el invierno para determinar su resistencia. No hubo reducciones en la resistencia para encino (Quercus acutissima), maple (Acer buergeranum), o ciprés (× Cupressocyparis leylandii). (Lagerstroemia indica), el cual es marginalmente resistente en pruebas locales y maple rojo (Acer rubrum) experimentaron diferencias, estadísticamente pero no biológicamente significativas, en pérdidas de resistencia en Enero y Febrero debido a algunos tratamientos con fertilizantes. 